\title{
PENGUJIAN RELIABILITAS ALAT UKUR THE PARENTING STYLES AND DIMENSION QUESTIONNAIRE (PSDQ)
}

\author{
Widya Risnawaty ${ }^{1}$, Agustina $^{2}$, Denrich Suyadi ${ }^{3}$ \\ ${ }^{1}$ Fakultas Psikologi, Universitas Tarumanagara Jakarta \\ Email:widyar@fpsi.untar.ac.id \\ ${ }^{2}$ Fakultas Psikologi, Universitas Tarumanagara Jakarta \\ Email:agustina@fpsi.untar.ac.id \\ ${ }^{3}$ Fakultas Psikologi, Universitas Tarumanagara Jakarta \\ Email:denrichs@fpsi.untar.ac.id
}

Masuk : 11-12-2020, revisi: 30-04-2021, diterima untuk diterbitkan : 30-04-2021

\begin{abstract}
Parenting pattern is a treatment of parents in terms of educating children, which includes a variety of behaviors to influence the behavior of the child. In today's society there is still a phenomenon where parents use violence to punish children, and is often interpreted as an educational punishment.There are still parents who do not realize that educating with violence can have a psychological impact on the child and potentially create problematic behaviors, trauma experiences to severe psychological disorders. The purpose of this study is to conduct psychometric tests on measuring instruments namely, Parenting Styles and Dimensions Questionnaire (PSDQ). Psdq measuring instrument used is the result of adaptation from Riany (2018) so it is already in the form of Indonesian language and indeed for use in Indonesia. This research uses quantitative method with sampling technique which is purposive sampling. The content validity test is conducted using an expert test of the statements in the questionnaire. The results of the evaluation from experts state that the whole item can be used without revision. The number of participants involved as many as 2153 participants consisting offather / mother. Research sites include Jakarta, Bandung, and Purwokerto. Reliability tests performed using internal consistency coefficient tests with Cronbach's alpha.. The results showed that 3 dimensions (permissive, authoritative, and authoritarian) in PSDQ proved to be valid and reliable. Total items in PSDQ measurement now 31 items, that means drop 1 item.
\end{abstract}

Keywords: measurement adaptation, $P S D Q$

ABSTRAK
Pola asuh merupakan suatu perlakuan orang tua dalam hal mendidik anak, yang meliputi beragam perilaku guna mempengaruhi perilaku anak. Dalam kondisi masyarakat saat ini masih ditemukan fenomena dimana orang tua menggunakan kekerasan untuk menghukum anak, dan seringkali dimaknai sebagai hukuman yang mendidik. Masih ada orang tua yang belum menyadari bahwa mendidik dengan kekerasan dapat menimbulkan dampak psikologis bagi anak dan berpotensi menciptakan perilaku-perilaku bermasalah, pengalaman trauma hingga gangguan psikologis berat.Tujuan dari penelitian ini adalah melakukan uji psikometri pada alat ukur yaitu, Parenting Styles and Dimensions Questionnaire (PSDQ). Alat ukur PSDQ yang digunakan adalah hasil adaptasi dari Riany (2018) sehingga sudah dalam bentuk bahasa Indonesia dan memang untuk digunakan di Indonesia. Penelitian ini menggunakan metode kuantitatif dengan teknik sampling yaitu purposive sampling. Uji validitas isi dilakukan dengan menggunakan uji pakar terhadap pernyataan dalam kuesioner. Hasil evaluasi dari pakar menyatakan bahwa keseluruhan butir dapat digunakan tanpa revisi. Jumlah partisipan yang dilibatkan sebanyak 2153 partisipan yang terdiri dari ayah/ibu. Lokasi penelitian meliputi Jakarta, Bandung, dan Purwokerto. Uji reliabilitas yang dilakukan menggunakan uji koefisien konsistensi internal dengan Cronbach's alpha. Hasil penelitian menunjukkan bahwa 3 dimensi (permissive, authoritative, authoritarian) dalam alat ukur PSDQ terbukti valid dan reliabel. Jumlah butir berkurang 1 butir, sehingga jumlah butir yang awalnya 32 berubah menjadi total 31 butir.

Kata Kunci: Adaptasi alat ukur, PSDQ 


\section{PENDAHULUAN}

\section{Latar Belakang}

Keluarga didefinisikan sebagai kelompok yang terdiri dari dua atau lebih, dimana orang-orang dalam kelompok tersebut saling terhubung karena kelahiran, perkawinan, atau adopsi, dan tinggal bersama dalam sebuah rumah tangga (Cohen \& Strong, 2020). Keluarga memegang peranan penting dalam proses pendidikan dan pembentukan fondasi untuk menjadi individu yang berkualitas (Sander, 1999; Gunarsa \& Gunarsa, 2008). Dalam penelitian Risnawaty (2017), dinyatakan bahwa kekuatan keluarga terletak pada bagaimana keluarga dapat membangun relasi yang sehat dan positif antara anggota keluarga. Namun pada kenyataannya, dalam masyarakat masih ditemukan fenomena dimana orang tua menggunakan kekerasan untuk menghukum anak, dan seringkali dimaknai sebagai "hukuman yang mendidik". Masih ada orang tua yang belum menyadari bahwa mendidik dengan kekerasan dapat menimbulkan dampak psikologis bagi anak dan berpotensi menciptakan perilaku-perilaku bermasalah, pengalaman trauma hingga gangguan psikologis berat.

Pada suatu penelitian tentang pola asuh yang dilakukan di Spanyol (Braza et al, 2013), dinyatakan bahwa ibu dengan tipe pola asuh otoriter dapat memengaruhi terbentuknya perilaku bermasalah pada anak, seperti bertindak agresif, menentang, mengalami gangguan cemas, menarik diri atau bahkan depresi. Hasil penelitian yang serupa juga ditemukan pada penelitian yang dilakukan oleh Martinez et al. (2018), bahwa pola asuh otoriter yang disertai dengan tekanan baik fisik maupun verbal berisiko membuat anak rentan menjadi korban perundungan. Sebaliknya pola asuh yang diekspresikan dalam perilaku yang hangat dan penuh pemahaman berfungsi sebagai faktor pelindung bagi anak dari potensi mengalami perundungan. Mengacu pada paparan hasil penelitian tersebut dapat ditarik satu pemahaman bahwa pola asuh yang bersifat positif dan tidak mengandung unsur kekerasan merupakan bentuk pola asuh yang diprediksi dapat mencegah terbentuknya perilaku bermasalah (Sanders, 1999; Sanders et al., 2000; Sanders, 2008).

Orang tua memiliki peran penting dan utama dalam pengasuhan anak (King, 2011; Berns, 2012). Orang tua berperan dalam menentukan pola asuh mana yang akan diterapkan pada anaknya (Darling, 1999). Pola asuh adalah suatu aktivitas yang kompleks, yang meliputi beragam tindakan dalam mempengaruhi perilaku anak. Pola asuh merupakan cara perlakuan orang tua dalam hal mendidik anak (Berns, 2012). Selain itu pola asuh juga dapat didefinisikan sebagai kumpulan tingkah laku orang tua yang terjadi pada beragam situasi (Berk, 2003). Berdasarkan definisidefinisi di atas, dapat disimpulkan bahwa pola asuh merupakan suatu perlakuan orang tua dalam hal mendidik anak, yang meliputi beragam perilaku guna mempengaruhi perilaku anak.

Baumrind (dalam Papalia \& Martorell, 2012) mengembangkan tiga tipe pola asuh yaitu: authoritarian, authoritative, dan permisif. Pola asuh authoritarian atau dikenal juga dengan sebutan otoriter merupakan pola asuh yang menekankan pada kontrol dan kepatuhan yang tidak perlu dipertanyakan lagi. Orang tua tipe ini mencoba membuat anak menyesuaikan standar perilaku tertentu dan menghukum mereka dengan paksa jika melanggar. Orang tua bersikap kurang hangat dibandingkan dengan orang tua lainnya. Pola asuh authoritative atau dikenal juga dengan sebutan demokratis, merupakan pola asuh yang menekankan pada individualitas anak, tetapi juga menekankan pada batasan sosial. Orang tua tipe ini menyayangi dan menerima tetapi juga menuntut perilaku yang baik dan tegas dalam mempertahankan standar. Mereka memberikan batasan, hukuman yang bijaksana ketika dibutuhkan, dalam konteks kehangatan, dan hubungan yang mendukung. Anak-anak merasa aman karena mengetahui bahwa orang tuanya menyayangi mereka dan apa yang diharapkan dari mereka. Pola asuh permissive (permisif) merupakan pola asuh yang menekankan pada ekspresi-diri dan regulasi-diri. Orang tua tipe ini hanya memberikan 
tuntutan yang sedikit. Mereka berkonsultasi dengan anak tentang keputusan aturan dan jarang menghukum. Mereka hangat, tidak mengontrol, dan tidak menuntut. Tujuan dari penelitian ini adalah untuk menguji secara psikometri alat ukur The Parenting Styles and Dimenssion Questionnaire (PSDQ), agar dapat digunakan para orang tua untuk mengetahui tipe pola asuh mana yang selama ini ia terapkan (Robinson et al., 1999). Alat ukur PSDQ ini dikembangkan oleh Clyde C. Robinson (1999) dengan mengacu pada teori dari Baumrind.

\section{Rumusan Masalah}

Alat ukur PSDQ sudah pernah diadaptasi di Indonesia (Riany et al., 2018) dengan menggunakan teknik confirmatory factor analysis, dan dalam hasil penelitian tersebut diperolah adanya perubahan faktor. Awal mulanya, PSDQ terdiri dari 3 faktor yang yaitu pola asuh permissive, authoritarian, dan authoritative. Setelah dilakukan uji psikometri, dihasilkan 3 faktor namun dengan komposisi yang berbeda dan salah satu faktornya yaitu permissive menjadi gugur. Faktor baru tersebut diberi nama faktor reasoning. Butir-butir yang terkumpul dalam faktor reasoning ini sebenarnya merupakan sempalan dari bagian faktor autoritharian. Kemudian dilakukan uji konsistensi internal pada 3 faktor baru tersebut menggunakan alpha Cronbach dan hasilnya menunjukkan reliabilitas 3 faktor baru tersebut reliabel (>0.7). Penelitian ini mecoba untuk melakukan pengujian reliabilitas dengan mengukur konsistensi internal menggunakan alpha Croncbach yang merujuk pada penelitian awal oleh Robinson dengan menguji 3 dimensi yaitu permissive, authoritarian, dan authoritative. Apakah pengujian terhadap dimensi permissive tetap reliabel untuk partisipan di Indonesia? Apakah butir-butir dimensi permissive tetap dapat digunakan dalam alat ukur? Bagaimana konsistensi internal untuk dua dimensi yang lain, yaitu authoritarian dan authoritative?

\section{METODE PENELITIAN}

Desain penelitian yang digunakan adalah penelitian kuantitatif yang ditujukan untuk menguji reliabilitas dan validitas dari alat ukur PSDQ. Teknik pemilihan sampel yang digunakan adalah purposive sampling. Teknik sampling ini dipilih karena partisipan yang akan dilibatkan dalam penelitian harus memenuhi beberapa kriteria tertentu, agar representatif dan dapat menjawab tujuan penelitian. Uji validitas isi dilakukan dengan menggunakan uji pakar terhadap pernyataan dalam kuesioner. Hasil evaluasi dari pakar menyatakan bahwa keseluruhan butir dapat digunakan tanpa revisi.

Partisipan yang dilibatkan pada penelitian ini sebanyak 2153 orang tua, yang terdiri dari 1130 ibu dan 1019 ayah, seluruhnya berdomisili di Jakarta. Unit analisis yang digunakan dalam penelitian ini adalah individu (ayah/ibu). Karakteristik subjek penelitian adalah sebagai berikut: (a) merupakan orang tua (ayah/ibu), (b) masih terikat dalam perkawinan, (d) memiliki anak yang berada dalam rentang usia 3-15 tahun, (e) tidak dibatasi oleh usia pernikahan, agama, suku bangsa maupun tingkat pendidikan. Lokasi penelitian meliputi daerah Jakarta, Bandung dan Purwokerto.

Instrumen penelitian yang digunakan dalam penelitian ini antara lain: (a) informasi tertulis penelitian, (b) pernyataan kesediaan untuk berpartisipasi (informed consent), (c) lembar identitas subyek, (d) kuesioner PSDQ yang sudah diadaptasi oleh Riany et.al, (2018). Parenting Styles and Dimension Questionnaire (PSDQ) memiliki 3 dimensi dengan total 32 butir, dan menggunakan skala Likert dengan rentang skala 1-5. Petunjuk skor skala yang digunakan: $1=$ tidak pernah, $2=$ sesekali 3 = hampir separuh waktu, $4=$ sering kali, $5=$ selalu 


\section{Gambaran partisipan}

Gambaran partisipan penelitian secara umum dapat dilihat dari data kontrol yang telah ditentukan. Gambaran data yang pertama dapat dilihat dari jenis kelamin subjek. Data yang diperoleh dari 2153 subyek, terdapat 1130 orang berjenis kelamin perempuan $(52.5 \%)$ dan 1019 orang berjenis kelamin laki-laki (47.3\%). Partisipan terbanyak dalam penelitian ini berjenis kelamin perempuan. Dari keseluruhan data, terdapat jenis kelamin subyek yang tidak terdeteksi sebesar 4 orang. Gambaran data dapat dilihat pada Tabel 1.

Tabel 1.

Gambaran Subyek Penelitian Berdasarkan Jenis Kelamin

\begin{tabular}{ccc}
\hline Jenis Kelamin & Frekuensi & Persentase \\
\hline Perempuan (ibu) & 1130 & 52.5 \\
Laki-Laki (ayah) & 1019 & 47.3 \\
Missing & 3 & .1 \\
Total & 2153 & 100
\end{tabular}

Data yang diperoleh dari 2153 subyek, terdapat 526 orang berdomisili di Bandung (24.4\%), 514 orang berdomisili di Purwokerto (23.9\%), dan 1113 orang berdomisili di Jakarta (51.7\%). Partisipan terbanyak dalam penelitian ini berdomisili di Jakarta. Gambaran data dapat dilihat pada tabel 2.

Tabel 2.

Gambaran Subyek Penelitian Berdasarkan Kota

\begin{tabular}{ccc}
\hline Kota & Frekuensi & Persentase \\
\hline Bandung & 526 & 24.4 \\
\hline Purwokerto & 514 & 23.9 \\
\hline Jakarta & 1113 & 51.7 \\
\hline Total & 2153 & 100
\end{tabular}

\section{HASIL DAN PEMBAHASAN}

\section{RELIABILITAS}

Hasil uji reliabilitas pada dimensi permissive menunjukkan koefisien alpha Cronbach sebesar .571. Hasil analisis menunjukkan bahwa tidak terdapat butir yang nilainya lebih kecil dari 0.2 , artinya seluruh 5 butirnya dapat digunakan. Butir-butir tersebut antara lain: 8, 15, 17, 20, 24. Hasil tersebut dapat dilihat dari Tabel 3.

Tabel 3.

Dimensi Permissive

\begin{tabular}{lccc}
\hline Dimensi & & Sebelum uji reliabilitas & Setelah uji reliabilitas \\
\hline Permissive & Butir positif & 5 & 5 \\
& Alpha Cronbach & .571 & .571 \\
Total & 5 & 5 \\
\hline
\end{tabular}

Dimensi yang kedua adalah dimensi authoritarian, yang memiliki 3 sub-dimensi, yaitu: (a) physical coercion, (b) non-reasoning/punitive, dan (c) verbal hostility. Pada pengujian berikut ini akan dilakukan untuk setiap sub-dimensi. Pada uji reliabilitas sub-dimensi physical coercion, hasil menunjukkan koefisien alpha Cronbach sebesar adalah .776. Hasil analisis menunjukkan bahwa dari keempat butir pernyataan tidak terdapat butir yang nilainya lebih kecil dari 0.2. Artinya 4 butir seluruhnya dapat digunakan, yaitu butir nomor: 4, 6, 19, 32. Hasil tersebut dapat dilihat dari Tabel 4. 
Tabel 4.

Sub-dimensi Authoritarian Physical Coercion

\begin{tabular}{llcc}
\hline Dimensi & & Sebelum uji reliabilitas & Setelah uji reliabilitas \\
\hline Physical Coercion & Butir positif & 4 & 4 \\
& Alpha Cronbach & .776 & .776 \\
Total & & 4 & 4 \\
\hline
\end{tabular}

Pada sub-dimensi non-reasoning/punitive dari dimensi pola asuh authoritarian menghasilkan koefisien alpha cronbach sebesar .591. Hasil analisis menunjukkan bahwa dari keempat butir pernyataan terdapat butir yang nilainya lebih kecil dari 0.2 , sehingga terdapat satu butir yang dibuang yaitu butir nomer 4 . Artinya tinggal 3 butir yang dapat digunakan yaitu butir nomor 10 , 26, dan 28. Hasil tersebut dapat dilihat dari Tabel 5.

Tabel 5.

Sub-dimensi Authoritarian Non-Reasoning/Punitive

\begin{tabular}{lccc}
\hline Dimensi & Sebelum uji reliabilitas & Setelah uji reliabilitas \\
\hline $\begin{array}{l}\text { Non- } \\
\text { Reasoning/Punitive }\end{array}$ & Butir positif & 4 & 3 \\
& & & \\
Total & Alpha Cronbach & .481 & .591 \\
\hline
\end{tabular}

Hasil uji reliabilitas menunjukkan koefisien alpha cronbach pada sub-dimensi verbal hostility pada dimensi pola asuh authoritarian adalah .624. Hasil analisis menunjukkan bahwa dari keempat butir pernyataan tidak terdapat butir yang nilainya lebih kecil dari 0.2. Artinya 4 butir tersebut seluruhnya dapat digunakan, yaitu butir nomer: 13, 16, 23, 30. Hasil tersebut dapat dilihat dari Tabel 6.

Tabel 6.

Sub-dimensi Authoritarian Verbal Hostility

\begin{tabular}{llcc}
\hline Dimensi & Sebelum uji reliabilitas & Setelah uji reliabilitas \\
\hline Verbal Hostility & Butir positif & 4 & 4 \\
& Alpha Cronbach & .624 & .624 \\
Total & & 4 & 4 \\
\hline
\end{tabular}

Hasil uji reliabilitas menunjukkan koefisien alpha cronbach pada sub-dimensi warmth \& support pada dimensi pola asuh authoritative adalah .675. Hasil analisis menunjukkan bahwa dari kelima butir pernyataan tidak terdapat butir yang nilainya lebih kecil dari 0.2 . 5 butir yang diujikan di awal dapat digunakan seluruhnya, yaitu butir nomor 7, 1, 12, 14, 27. Hasil tersebut dapat dilihat dari Tabel 7.

Tabel 7.

Sub-dimensi Authoritative Warmth \& Support

\begin{tabular}{llcc}
\hline Dimensi & & Sebelum uji reliabilitas & Setelah uji reliabilitas \\
\hline Warmth \& Support & Butir positif & 5 & 5 \\
& Alpha Cronbach & .675 & .675 \\
Total & & 5 & 5 \\
\hline
\end{tabular}


Pada sub-dimensi autonomy granting dari dimensi pola asuh authoritative, hasil uji reliabilitas menunjukkan koefisien alpha cronbach adalah .638. Hasil analisis menunjukkan bahwa dari kelima butir pernyataan tersebut tidak terdapat butir yang nilainya lebih kecil dari 0.2 , Berikut nomor butir yang dapat digunakan, yaitu: 3, 9, 18, 21, 22. Hasil tersebut dapat dilihat dari Tabel 8.

Tabel 8.

Sub-dimensi Authoritative Autonomy Granting

\begin{tabular}{llcc}
\hline Dimensi & & Sebelum uji reliabilitas & Setelah uji reliabilitas \\
\hline Autonomy Granting & Butir positif & 5 & 5 \\
& Alpha Cronbach & .638 & .638 \\
Total & & 5 & 5 \\
\hline
\end{tabular}

Hasil uji reliabilitas menunjukkan koefisien alpha cronbach pada sub-dimensi regulation pada dimensi pola asuh authoritative adalah .771. Hasil analisis menunjukkan bahwa dari kelima butir pernyataan tidak terdapat butir yang nilainya lebih kecil dari 0.2. Adapun kelima butir yang reliabel tersebut adalah butir nomor 5, 11, 25, 29, 31. Hasil tersebut dapat dilihat dari Tabel 9.

Tabel 9.

Sub-dimensi Authoritative Regulation

\begin{tabular}{llcc}
\hline Dimensi & & Sebelum uji reliabilitas & Setelah uji reliabilitas \\
\hline Regulation & Butir positif & 5 & 5 \\
& Alpha & .771 & .771 \\
Total & Cronbach & 5 & 5 \\
\hline
\end{tabular}

Setelah dilakukan uji reliabilitas, maka dapat diperoleh informasi lain terkait dengan gambaran pola asuh dari para partisipan. Hasil penelitian yang diperoleh menggambarkan pula mengenai pola asuh orang tua yang digunakan oleh partisipan penelitian. Pola asuh partisipan terdiri dari 3 dimensi yaitu, permissive, authoritarian, dan authoritative dan masing-masing dimensi memiliki mean hipotetik (median) sebesar 3. Pada pola asuh permissive ditemukan skor mean empirik adalah 3.6901. Skor mean empirik pada pola asuh permissive sedikit lebih tinggi dari mean hipotetik sehingga dapat dikatakan bahwa kecenderungan subyek menggunakan pola asuh permissive cenderung tinggi. Mean empirik dari pola asuh authoritarian adalah sebesar 4.2198, sekor tersebut lebih tinggi daripada mean hipotetik. Hal tersebut berarti penggunaan pola asuh authoritarian oleh subyek dapat dikatakan tinggi. Pada pola asuh authoritative ditemukan mean empirik sebesar 1.8864. Skor tersebut lebih rendah dari skor mean hipotetik sehingga dapat dikatakan bahwa penggunaan pola asuh authoritative oleh subyek cenderung rendah. Berdasarkan hasil analisis data pada 2153 partisipan, penggunaan pola asuh permissive dan pola asuh authoritarian cenderung tinggi. Gambaran variabel secara singkat dapat dilihat dari Tabel 10.

Tabel 10.

Gambaran Data Pola Asuh

\begin{tabular}{lccccc}
\hline & N & Minimum & Maximum & Mean & $\begin{array}{c}\text { Std. } \\
\text { Deviation }\end{array}$ \\
\hline Permissive & 2153 & 1.00 & 5.00 & 3.6901 & .66836 \\
Authoritarian & 2153 & 1.00 & 5.00 & 4.2198 & .55902 \\
Authoritative & 2153 & 1.00 & 5.00 & 1.8864 & .59075 \\
\hline
\end{tabular}


Papalia dan Martorell (2012) mengatakan bahwa pola asuh authoritative merupakan pola asuh yang menekankan pada individualitas anak, tetapi juga menekankan pada batasan sosial. Anakanak merasa aman karena mengetahui bahwa orang tuanya menyayangi mereka dan apa yang diharapkan dari mereka (Papalia \& Martorell, 2012). Hasil penelitian ini sejalan hasil penelitian Sumargi dan Kristi (2017) yang menunjukkan bahwa kondisi well-being orang tua berkorelasi secara positif dengan pengasuhan authoritative dan pengasuhan authoritative berkorelasi negatif dengan perilaku bermasalah pada remaja. Selanjutnya, Yusuf (2013) menjelaskan hasil penelitiannya yang menunjukkan bahwa dari data yang didapatkan, terlihat adanya pengaruh masing-masing jenis pola asuh orang tua yaitu pola asuh authoritative, permissive dan authoritarian terhadap tingkat kooperatif anak usia 3-5 tahun. Hasil dari setiap jenis pola asuh ini kemudian dibandingkan satu sama lain untuk dianalisis mana yang lebih besar pengaruhnya dalam meningkatkan perilaku kooperatif anak usia 3-5 tahun dan diketahui bahwa yang paling besar pengaruhnya adalah orang tua yang memiliki pola asuh authoritative, diikuti dengan permissive dan authoritarian.

Adapun Anggoro (2016) menyebutkan bahwa pada orang tua yang lebih sering menerapkan pola asuh authoritartive lebih berpotensi mengembangkan motorik anak (baik motorik kasar maupun halus) dengan lebih baik dibandingkan dengan pola asuh permissive. Hal ini disebabkan karena orang tua memberi anak kebebasan untuk berkreasi dan mengeksplorasi berbagai hal sesuai dengan kemampuan anak dengan sensor batasan dan pengawasan yang baik dari orang tua, sedangkan pada pola asuh permissive anak kurang mendapat bimbingan dari orang tua untuk melewati setiap tahap perkembangannya, sehingga perkembangan anak tidak sesuai dengan tahap perkembangannya.

\section{KESIMPULAN DAN SARAN}

Dalam penelitian ini dapat ditarik kesimpulan bahwa proses adaptasi alat ukur PSDQ yang telah dilakukan menunjukkan bahwa alat ukur PSDQ telah terbukti valid dalam hal konten dan reliabel untuk ketiga dimensinya, dengan jumlah total butir beruban menjadi 31 butir. Adapun rinciannya sebagai berikut: (a) dimensi permissive terdiri dari 5 butir, (b) dimensi authoritarian gugur 1 butir hingga menjadi 11 butir, dan (c) dimensi authoritative terdiri dari 15 butir. Hasil lain yang juga dapat diperoleh adalah gambaran tentang penyebaran data pola asuh diantara 2153 partisipan. Berdasarkan analisis data dapat disimpulkan bahwa pola asuh yang paling banyak dilakukan oleh para partisipan adalah pola asuh authoritative, dan urutan yang kedua adalah pola asuh permissive. Pola asuh authoritarian memiliki mean yang paling rendah dibandingkan 2 pola asuh yang lain. Terkait dengan pengembangan alat ukur PSDQ ini, maka alat ukur ini dapat digunakan untuk berbagai penelitian yang terkait dengan pola asuh orang tua.

\section{Ucapan Terima Kasih (Acknowledgement)}

Kami mengucapkan terima kasih kepada Ristekdikti yang telah memberikan bantuan dana penelitian dan pihak LPPM Universitas Tarumanagara yang telah mengelola dan mengoordinir pelaksanaan penelitian ini, sehingga penelitian ini dapat terlaksana. Kami ucapkan terima kasih pula kepada seluruh pihak yang telah berkontribusi dalam penelitian, antara lain: pihak sekolah di Purwokerto dan Bandung, dan seluruh asisten penelitian.

\section{REFERENSI}

Anggoro, I. S., (2016). Gambaran pola asuh orang tua pada anak dengan penyakit jantung bawaan asianotik terhadap perkembangan motorik di rumah sakit phc Surabaya. Universitas Katolik Widya Mandala Surabaya.

Berk, L. A. (2003). Child development. Allyn \& Bacon. 
Braza, P., Carreras, R., Munoz, J. M., Braza, F., Azurmendi, A., Pascual-Sagastizábal, E., Cardas, J., \& Sánchez-Martín, J. R. (2013). Negative maternal and paternal parenting styles as predictors of children's behavioral problems: Moderating effects of the child's sex. Springer Science+Business Media New York. https://doi.org/10.1007./s10826-013-98930 .

Berns, R. M. (2012). Child, family, school, community: Socialization and support. Wadsworth, Cengage Learning.

Cohen, T. F., \& Strong, B. (2020). The marriage and family experience: Intimate relationships in a changing society. Cengage Learning.

Darling, N. (1999). Parenting styles and it correlates. Eric Digest. http://www.ericdigests.org/19994/parenting.htm

Gunarsa, S.D \& Gunarsa, Y. S. D. (2008). Psikologi praktis: Anak, remaja, dan keluarga. Gunung Mulia.

King, L. A. (2011). The science of psychology: An appreciative view. McGraw-Hill.

Martinez, I., Murgu, S., Garcia, O., F., \& Garcia, F. (2018). Parenting in the digital era: Protective and risk parenting styles for traditional bullying and cyberbullying victimization. Computers in Human Behavior. https://doi.org/10.1016/j.chb.2018.08.036.

Papalia, D. E., \& Martorell, G. (2012). Experience human development (12 ${ }^{\text {nd }}$ ed.). McGraw-Hill.

Riany, Y. E., Cuskelly, M., \& Meredith, P. (2018). Psychometric properties of parenting measures in Indonesia. Makara Human Behaviour Studies in Asia, 22(2), 75-90.

Risnawaty, W. (2017). Gambaran kekuatan keluarga pada etnis Jawa: Studi pada kasus tunggal. Jurnal Muara Ilmu Sosial, Humaniora, dan Seni, 1(2), 465-472. ISSN-L 2579-6356.

Robinson, C.C., Mandleco, B., Olsen S.F., Hart, C.H. (1999). Authoritative, authoritarian, and permissive parenting practices: Development of a new measure. Psychological Report. 77,819-830.

Sanders, M. R. (1999). Triple p-positive parenting program: Towards an empirically validated multilevel parenting and family support strategy for the prevention of behavior and emotional problems in children. Clinical Child and Family Psychology Review, 2 (2), 7190.

Sanders, M. R., Markie-Dadds, C., Tully, L. A, Bor, W. (2000). Triple p-positive parenting program: A comparison of enhanced, standard, and self-directed behavioral family intervention for parents of children with early onset conduct problems. Journal of Consulting and Clinical Psychology, 68 (4), 624-640. https://doi.org/ I0.1037OT022006X.68A624

Sanders, M. R. (2008). Triple p-positive parenting program as a public health approach to strengthening parenting. Journal of Family Psychology, 22 (3), 506-517. https://doi.org/10.1037/0893-3200.22.3.506

Sumargi, A. M., \& Kristi, A. N. (2017). Well-being orang tua, pengasuhan otoritatif, dan perilaku bermasalah pada remaja. Jurnal Psikologi UGM, 44 (3), 185-197.

Yusuf, H. (2013). Pengaruh pola asuh orang tua terhadap tingkat kooperatif anak usia 3-5 tahun dalam perawatan gigi dan mulut. Universitas Hasanuddin Makassar. 